\section{POULTRY GENETICS}

Genetics of the Fowl

By Prof. F. B. Hutt. (MeGraw-Hill Publications in the Agricultural Sciences.) Pp. xi+590. (London: McGraw-Hill Publishing Co., Ltd., 1949.) 55s. 6d.

$\mathrm{A}$ $\mathrm{N}$ exhaustive compendium on the genetics of the domestic fowl has been wanting for a long time. The author now provides one which is in the same noteworthy class as the works of Grüneberg on the rat and Stern on man. This book is likely to be the standard work on the subject for many years. The literature on poultry genetics is already large, the number of references given being about 1,150 ; in a volume of 590 pages this means an average of about half a page per reference, so that the reader will generally find information about every conceivable aspect of poultry genetics usefully and skilfully concentrated. It is possible, however, that authors from the Continent of Europe do not always receive their fair share of attention, this being a not infrequent fault in books written by authors whose mother tongue is English.

There are fifteen chapters in all, the most useful to the breeder being those on egg production, genetic resistance to disease, and genetics in practice. One could have wished for a more extended consideration of this last subject, as it is here that the wisdom and sound judgment of the author are made most evident. In spite of his obviously great technical knowledge he admits that it is "with considerable misgiving that the author ventures to suggest how to improve our domestic fowls by. breeding". A careful reading of the chapter on genetics in practice leads me to advise the author to get rid of this miggiving as soon as possible.

Knowledge about any useful animal can almost always be of use to workers on other animals. It is not clear whether the gigantic egg-production scheme of the Gambia is under competent genetic guidance ; but if it is not, the authorities may like to take to heart the valuable information given on pages $439-40$ about the behaviour of stock bred in one country when transferred to another. The Gambia scheme involves the use of vast numbers of the Rhode Island Red breed imported from the United States. It is here pointed out that breeds and strains of fowls which are excellent in one part of the world are often quite unsuitable when transferred to another. This is particularly the case with birds imported to tropical countries from Europe and North America. In most cases the imported stock is susceptible to diseases and parasites to which it had not previously been exposed. By contrast the native fowls are much hardier and, one might add, will respond quickly to genetical selection at higher nutritive levels than those to which they are accustomed.

The author also points out that genetical considerations are often ignored in the control of disease. This is mainly due to the fact that methods of control are based on the recommendations of bacteriologists and veterinarians, whose sole aim is to eradicate the disease. In the case of the pullorum disease of fowls, this is done by eliminating all birds carrying the pullorum organism. The author states: "In the attempt to accomplish it, one envisions little armies of blood testers struggling on to the millennium, while as a result of their labours the poultry population, in the absence of any natural selection, becomes more and more susceptible'. Should not, we might ask, genetical considerations play a large part in the control of tuberculosis and of foot and mouth disease in cattle?

This book should be used as a work of reference by geneticists, animal breeders and general biologists. There are a few misprints.

S. C. Harland

\section{PETROLEUM IN PRODUCTION AND REVIEW}

\section{Conversion of Petroleum}

Production of Motor Fuels by Thermal and Catalytic Processes. By Dr. A. N. Sachanen. Second edition, revised and enlarged. Pp. xii +602 . (New York: Reinhold Publishing Corporation; London: Chap. man and Hall, Ltd., 1948.) 66s. net.

\section{Petroleum Production}

By Park J. Jones. Vol. 5 : Oil Production by Gas and Flooding. Pp. vii + 274. (New York: Reinhold Publishing Corporation; London: Chapman and Hall, Ltd., 1948.) 36s. net.

Reviews of Petroleum Technology

Vol. 8 (covering 1946). Pp. viii +445 . (London : Institute of Petroloum, 1949.) 27s. $6 d$.

THERE has probably never been a time in the history of the oil industry when 'petrol', to use the colloquial term, has engaged so forcibly public attention in Great Britain and elsewhere. Once rationing is imposed on any commodity which has been taken for granted, as up. to 1939 petrol certainly was and likewise food (water has always been), there is solid basis for the ordinarily complacent citizen to know the reason why and to bestir himself to the facts. Even to keep a ration going for vital needs in time of emergency and stress is a formidable task; had it not been for amazing advances in technique of producing motor fuels by processes developed during the Second World War and afterwards, one wonders whether, indeed, economic factors aside, the petrol ration would not be with us in Britain and in Europe generally for years to come.

The explanation of these advances is, of course, highly technical; it rests on the extraordinary rate of evolution in refinery procedure during the past decade and on conversion of petroleum in the more or less raw state into motor fuels by specialized thermal and catalytic processes. Dr. A. N. Sachanen devotes his large book to this complex subject and, to the technologist, shows how catalytic eracking, alkylation, thermal cracking, polyforming, and making petroleum gas into fuel by Fischer-Tropsch processes have contributed to the position now realized. Commercialization of relatively minor developments, for example, catalytic isomerization, hydroforming and dehydrogenation, are ancillary. The book is a thoroughly up-to-date treatise on these matters.

On the production side, to add to efficiency of winning crude oil under varying structural conditions, Park J. Jones has written a graphic account of the mechanism of gas and flooding to liberate supplies. This is Vol. 5 of an extensive review on petroleum production methods in different reservoirs, and is clearly the work of a specialist who can visualize the shape of, and fluid conditions obtaining in, oil-pools and can lay down precepts for making the most of the 